\title{
伝える
}

\section{谷本 正幸}

名古屋大学 大学院 教授

自分で何かを実現したとき，そのことを他の人に知っ てもらうには, 情報を伝達することが必要です. 発信し たい情報を持っているとき，それを他の人にどのように 伝えればよいでしょうか. この, 情報を伝達する手段, 伝える手段として何が効果的かを, 私の体験より述べた いと思います。

以前, 本誌2001年12月号の “ふおーかす”に「自由視点 テレビ」と題して記事を書かせて頂きました，その中で， ユーザが自由に場所を移動したり視線を変えたりしなが ら情景を見ることのできるテレビとして, 自由視点テレ ビ FTV (Free viewpoint TV) を提唱しました。

それから6年が経ちました。この間に，私たちは撮影か ら表示までをリアルタイムで行うFTVシステムや大規模 空間を撮影する100眼システムを実現しました. MPEGで はFTVの国際標準化活動が始まっています.

このような状況をより多くの人に知って頂くため, 研 究成果を伝える努力を行ってきました．私たちが利用で きる情報の伝達手段には, 伝達範囲の広いものから順に, メディア, 学会, 講演会等があります.

メディアの代表は新聞や放送です．放送の経験はあり ませんが, 新聞や雑誌でFTVの紹介をして頂いたことが あります。しかし，それによってFTVがよく知られるよ うになったとはいえません.メディアに載れば多くの人 に伝わるのではないかと思っていましたが, 甘い考えで した.

それでは, 学会はどうでしょうか. 学会では研究結果
を先に発表したものが勝ちで, 2番目や3番目に発表して も評価されません. また，同じことを 2 回発表してはいけ ないというのが学会のルールです。このため, 研究成果 を学会で一度でも発表すれば, その内容は研究者に伝わ ると思っていましたが, 現実はそうではありませんでし た. 学会での発表は新規性の主張には役立ちますが, 伝 えるためには充分ではありません，発表者がこれはすば らしい成果であると言っても, そのように言う人は他に もたくさんいますので, 普通は無視されてなかなか聞い てもらえません. 大抵の場合, 言いっぱなし, 伝えっぱ なしになってしまいます.

これに対して, 講演会では会場からの反応があります。 ある講演会の閉会の挨拶で, 主催者側の著名な元大学教 授が,「今日の名古屋大学の先生の話は大変面白かった. しかし, 大学の先生というものはできないものを, さも できたように話すものです」と言われて，会場が懪笑と なりました。この方はこのような表現をされましたが， その表情からFTVの意義をよく理解して頂けたと確信で きました.

しかし, 最も効果的だったのは, このような大勢の人 を対象とした伝達ではなく, 個人的なつながりやさまざ まな出会いの折りの, 直接対話でした。私たちは映像情 報メディア技術の研究開発に携わっていますが, 情報を 伝えるには，相手の反応が即座にわかり，それによって 瞬時に対応可能な, 対面のコミュニケーションが最も有 効であるというのが, 私の体験による結論です. 